\title{
Assessing Some Indicators Of Tourism Sustainability: Case Study From Armenia
}

\author{
https://doi.org/10.21272/sec.3(1).127-136.2019
}

\section{Gayane Tovmasyan}

$\mathrm{PhD}$ in Economics, Senior Researcher at "AMBERD" Research Center of the Armenian State University of Economics, Professor at the Public Administration Academy of the Republic of Armenia, the Republic of Armenia

\begin{abstract}
This paper summarizes the arguments and counterarguments within the scientific discussion on the issues of possible effects of tourism on sustainable development. Sustainable tourism must contribute to meeting the visitor needs, maintaining the environment and raising the wellbeing of host communities, developing economy and local culture.

The main purpose of the research is to analyze the meaning of the sustainable tourism, aims and directions. The article presents the essence of sustainable tourism, aims identified by UNWTO and UNEP, pillars identified by UNWTO, the European Tourism Indicator System (ETIS) launched by European Commission. The article evaluates some indicators of sustainable tourism in Armenia using the following seven dimensions: tourism assets, tourism activity, tourism-related linkages, tourism-related leakages, environmental and social sustainability, overall infrastructure, attractiveness.

The investigation of the topic shows, that the whole world walks towards sustainability. The global challenges are of high importance and every country must think about the negative effects of global warming, pollution, degradation, poverty, etc. The empirical analysis shows that there are many problems in sustainable development of tourism in Armenia. The research empirically confirms and theoretically proves that Armenia has a great potential for tourism development and steps must be undertaken to increase the environmental, cultural sustainability, develop infrastructures, raise competitiveness, etc. The main conclusion is that for sustainable development of tourism it is necessary to raise public consciousness and knowledge of other aspects of ecology and sustainable tourism, use renewable energy sources, ensure sustainable landfill and waste management, use electric or hybrid vehicles, etc. Sustainable tourism development in Armenia should contribute to socio-economic, cultural and environmental development of the country. The results of the research can be useful for the state organs, private sector, also for researchers of tourism sphere.
\end{abstract}

Keywords: attractiveness, evaluation, infrastructure, indicator, sustainability, tourism.

JEL Classification: L83, Q01, Z3.

Cite as: Tovmasyan, G. (2019). Assessing some indicators of tourism sustainability: case study from Armenia. SocioEconomic Challenges, 3(1), 127-136. https://doi.org/10.21272/sec.3(1).127-136.2019.

(C) The Author, 2019. This article is published with open access at Sumy State University.

\section{Introduction}

Sustainable tourism may be described as visiting a place as a tourist and trying to make only positive impact on the economy, culture and environment of the destination. Tourism may have both positive and negative impacts. The aim of sustainability is to provide only positive impact by insuring social and economic development, local prosperity, visitor fulfillment, environmental purity, cultural richness, etc. It is necessary to take many steps in Armenia towards insuring sustainable development of tourism. So the article aims at assessing the current state of sustainability, in order to reveal the main issues and find solutions for.

Tourism as a global phenomenon develops very fast and year by year involves more and more people. The number of international tourist arrivals increased from 25 million (1950) up to 1,322 million in 2017. For 2050 the forecast is 1,874 million tourists in the world (UNWTO Tourism Highlights, 2016). The total contribution of Travel \& Tourism to GDP was USD 8,272.3bn (10.4\% of GDP) in 2017 in the world, the total contribution of Travel \& Tourism to employment was $9.9 \%$ of full employment including jobs $(313,221,000)$ 
indirectly supported by the industry, Travel \& Tourism investment in 2017 was USD $882.4 \mathrm{bn}$, or $4.5 \%$ of total investment (Travel \& Tourism Economic Impact World, 2018).

Here are some examples of our impact on environment (Sustaining tourism):

$\checkmark \quad 10,000$ people arrive in the Mayan Riviera every day - a destination where there is still no proper recycling,

$\checkmark \quad$ The average Canadian household used 326 litres of water per day....a village of 700 in a developing country uses an average of 500 litres of water per month and a luxury hotel room guest uses 1800 litres of water per person per night,

$\checkmark$ The average person in the UK uses approximately 150 litres of water per day -3 times that of a local village in Asia,

$\checkmark$ A species of animal or plant life disappears at a rate of one every three minutes,

$\checkmark 70 \%$ of marine mammals are threatened,

$\checkmark$ The Western world (with $17 \%$ of the worlds' population) currently consumes $52 \%$ of total global energy,

$\checkmark \quad 1$ acre of trees absorbs 2. 6 tonnes of $\mathrm{CO} 2$ per year,

$\checkmark$ Eating beef is the most water consumptive practice by travellers,

$\checkmark$ Seawater is expected to rise $70 \mathrm{~cm}$ in the next 10 years

$\checkmark$ By 2050 climate change could have directly led to the extinction of $30 \%$ of species, the death of $90 \%$ of coral reefs and the loss of half the Amazon rainforest,

$\checkmark$ Since 1970 a third of the natural world has been destroyed by human activity. Almost 2/3 are degraded by human activity,

$\checkmark$ Half the world's population lives in urban areas and this figure is expected to increase. In Latin America and the Caribbean, $76 \%$ of the population live in urban areas,

$\checkmark$ The number of cars on the road surpassed 1 billion in 2010. Today it is 1.2 billion and will be 2 billion by 2035 ,

$\checkmark$ A European uses 14x more energy than someone living in India,

$\checkmark$ For every 1 degree rise in temperature above 34 degrees Celsius, yields of rice, maize and wheat in tropical areas could drop by $10 \%$,

$\checkmark$ Every year we dump 40 million tons of carbon pollution into our atmosphere.

$\checkmark$ Although $70 \%$ of the earth's surface is water, only $3 \%$ is potable.

So, here comes the need of sustainable tourism which will lead to sustainable use of all resources.

\section{Literature review}

Today many countries understand the necessity of sustainable development. Sustainable tourism issues are of high importance. It was firstly presented as nature and soft tourism. However, up until the late 19th century, nature journeys were not very popular. "Nature tourism" came into existence with the first discovery tours to the European Alps and the establishment of Alpine Associations. Up until the mid-20th century, world trips remained possible only for the upper class. It was not until the technological development of the transport system and mass communication that more and more people started travelling. Then term 'Soft Tourism" was introduced in German-speaking countries in 1980, when futurologist Robert Jungk presented 'Soft Travelling" as opposed to 'Rough Travelling" of mass tourism in the magazine GEO. Soft Tourism was aimed at reducing or undoing consequences of tourism development by taking restrictive measures within spatial planning and regional policies and avoiding those consequences in the future. During the 90s, the concept of Soft Tourism was increasingly replaced by discussions about 'Sustainable Tourism'. The term 'Ecotourism" was introduced in 1965, when ecological issues were first integrated in tourism. It was mainly considered to be a form of tourism confined to visiting protected areas. This definition was later expanded to include near-nature areas and the interests of the local population. Due to its focus on ecological issues only (apart from the fact that planes are the means of travel often used for ecotourism offers, despite their big footprint), Ecotourism is not compatible with the holistic objectives of Sustainable Development (Baumgartner, C., 2008).

The UN World Commission on Environment and Development adopted the idea of sustainability in the "Brundtland report" in 1987 and defined sustainable development as follows: 'Sustainable development is a process to meet the needs of the present without compromising the ability of future generations to meet their own needs". 
This concept has evolved since 1987, through Agenda 21, the plan of action which emerged from the UN Conference on Environment and Development (Rio, 1992), and the plan of implementation from the World Summit on Sustainable Development (Johannesburg, 2002).

Three dimensions or pillars of sustainable development are now recognized and underlined. These are:

$\checkmark$ Economic sustainability, which means generating prosperity at different levels of society and addressing the cost effectiveness of all economic activity.

$\checkmark$ Social sustainability, which means respecting human rights and equal opportunities for all in society.

$\checkmark$ Environmental sustainability, which means conserving and managing resources, especially those that are not renewable or are precious in terms of life support.

UNWTO has defined sustainable tourism as "tourism that takes full account of its current and future economic, social and environmental impacts, addressing the needs of visitors, the industry, the environment and host communities". Sustainable tourism should:

- Make optimal use of environmental resources that constitute a key element in tourism development, maintaining essential ecological processes and helping to conserve natural resources and biodiversity.

- Respect the socio-cultural authenticity of host communities, conserve their built and living cultural heritage and traditional values, and contribute to inter-cultural understanding and tolerance.

- Ensure viable, long-term economic operations, providing socio-economic benefits to all stakeholders that are fairly distributed, including stable employment and income-earning opportunities and social services to host communities, and contributing to poverty alleviation (Making Tourism More Sustainable, 2005).

The need of sustainability arose from the recognition that the earth's limited resources could not support the rapid population and industrial growth as economic development moves to reduce poverty and increase standards of living among all countries. Most tourists wish to visit areas that are attractive, functional, clean and not polluted. Tourism can provide the incentive and means to maintain and, where needed, improve the environmental quality of areas. A high level of environmental quality is also very important for the local residents to enjoy. Tourism can help make residents more aware of the quality of their environment and support its maintenance and, where necessary, improvement (Neto, F., 2002).

By the early 1990s, the attention paid to both the perceived negative impacts of tourism and to alternative approaches to its development had become re-focused through the specific lens of sustainable tourism and, since then, it has maintained a dominant position in both the academic study of tourism and in tourism policy and planning processes (Ashley, et al., 2001).

The definitions of sustainable tourism emphasize the following important features: quality, continuity and balance (Tao, 2005).

Sustainable tourism is considered to be that form of tourism that favors long term management of resources in such a manner that the economic and social needs be met, maintaining cultural integrity, essential ecological processes, biodiversity and vital needs feedback systems (Sandra, Jean-Marie, 2004).

Driml (1996) refers to 'sustainable activity' when talking about the emergent phenomenon of linking industry sectors' names with the concepts of sustainable development, following its popularization. However, it could be argued that the evolution of the concept of 'sustainable tourism' was evident in the literature before the term sustainable development was officially used. An example of this is Rosenow and Pulsipher (1979), who called for 'new tourism' which could preserve towns, not exceed carrying capacities, enhance environmental and heritage values and educate tourists. Other examples include Butler's Destination Life Cycle Model (Butler, 1980), which has been argued as reflecting the concept of sustainable development indirectly (Hunter, 1995) and the concept of carrying capacity (Stankey, 1973; Tivy, 1973).

The differences in attitudes towards sustainable tourism are also evident in the way in which it is defined. Some advocates of sustainable tourism tend to define it as a parochial, sectoral term, emphasizing growth in order for viability to be maintained. It has been argued that although the concept may have areas of mutual concern with sustainable development, it has its own specific tourism-centric agenda (Butler, 1993; Hunter, 1995; Wall, 1997). Consequently, these authors prefer to use the term sustainable development in the context of tourism, rather than sustainable tourism, in order to prevent the parochial assumption implied in the term 
sustainable tourism. In contrast to parochial definitions, many authors have tended to define sustainable tourism in broader terms, transferring the principles of sustainable development into the context of tourism needs (Bramwell \& Lane, 1993; Ding \& Pigram, 1995; Hunter 1997; Muller, 1994; Sadler, 1993). Hunter (1997) has suggested a spectrum of four sustainable tourism approaches, based loosely on interpretations of sustainable development. This adaptive approach has been advocated by several other authors whose definitions range from being weak (emphasising satisfaction of tourists) through to strong (whereby tourism may only be allowed to operate at a small scale) (Carlsen, 1997; Coccossis, 1996).

The main environmental impacts of tourism are: threats to ecosystems and biodiversity (loss of wildlife and rare species, habitat loss and degradation), disruption of coasts (shoreline erosion and pollution, impact to coral reefs and fish spawning grounds), deforestation (loss of forests for fuel wood and timber by the tourist industry also impact on soil and water quality, bio-diversity integrity, reducing the collection of forest products by local communities), water overuse (as a result of tourism/recreational activities), urban problems (congestion and overcrowding, increased vehicle traffic and resultant environmental impacts, including air and noise pollution, and health impacts), exacerbate climate change from fossil fuel energy consumption for travel, hotel and recreational requirements, unsustainable and inequitable resource use, energy and water over consumption, excessive production of wastes, litter and garbage (UNEP, 2002).

The main negative economic impacts of tourism are: inflation; dominance by outsiders in land and property markets; inward-migration eroding economic opportunities for domestic industry including the poor, economic instability, crowding, excessive development, seasonal character of jobs, etc. Tourism may also have negative socio-cultural impacts: community conflict, cultural change, loss of authenticity, standardization, crime generation, etc.

The main stakeholders of sustainable tourism are: international development assistance agencies, national government, local government and destination bodies, private sector businesses, employees and related bodies, NGOs - international, national and local, education and training bodies, local community, consumers/tourists.

UNWTO and UNEP identified 12 aims for sustainable tourism:

1. Economic viability: to ensure the viability and competitiveness of tourism destinations and enterprises, so that they are able to continue to prosper and deliver benefits in the long term.

2. Local prosperity: to maximize the contribution of tourism to the prosperity of the host destination, including the proportion of visitor spending that is retained locally.

3. Employment quality: to strengthen the number and quality of local jobs created and supported by tourism, including the level of pay, conditions of service and availability to all without discrimination by gender, race, disability or in other ways.

4. Social equity: to seek a widespread distribution of economic and social benefits from tourism throughout the recipient community, including improving opportunities, income and services available to the poor.

5. Visitor fulfillment: to provide a safe, satisfying and fulfilling experience for visitors, available to all without discrimination by gender, race, disability or in other ways.

6. Local control: to engage and empower local communities in planning and decision making about the management and future development of tourism in their area, in consultation with other stakeholders.

7. Community wellbeing: to maintain and strengthen the quality of life in local communities, including social structures and access to resources, amenities and life support systems, avoiding any form of social degradation or exploitation.

8. Cultural richness: to respect and enhance the historic heritage, authentic culture, traditions and distinctiveness of host communities.

9. Physical integrity: to maintain and enhance the quality of landscapes, both urban and rural, and avoid the physical and visual degradation of the environment

10. Biological diversity: to support the conservation of natural areas, habitats and wildlife, and minimize damage to them.

11. Resource efficiency: to minimize the use of scarce and non-renewable resources in the development and operation of tourism facilities and services.

12. Environmental purity: to minimize the pollution of air, water and land and the generation of waste by tourism enterprises and visitors (Making Tourism More Sustainable, 2005). 
UNWTO has identified five pillars which cover the thematic areas which could be addressed through future projects and interventions for making tourism sustainable. The pillars are related to the aims of sustainable tourism.

$\checkmark$ Tourism policy and governance pillar concerns the recognition of tourism in sustainable development policies and the presence and implementation of a clear tourism strategy that embraces sustainability principles. It looks at tourism governance structures, including tourism ministries and institutions and how they relate to other areas of government that affect its sustainability and performance. It also considers the presence of structures and mechanisms for engaging public, private and third sector stakeholders, including local communities, at different levels.

$\checkmark$ Economic performance, investment and competitiveness pillar considers the business and investment environment and the position of trade liberalization in the tourism sector, including the consequences for the local economy, small businesses and sustainability in general. It looks specifically at issues of market access, product quality and the resilience of the sector. It recognizes the need for sound data to inform tourism planning and management.

$\checkmark$ Employment, decent work and human capital pillar is concerned partly with the planning of human resources to meet the needs of the sector and partly with the quality of jobs provided, including conditions of employment. Skills assessment and provision of relevant training and capacity building is covered as a specific theme.

$\checkmark$ Poverty reduction and social inclusion pillar focuses on the contribution of tourism to poverty reduction. It considers a strategic approach to pro-poor tourism at a destination level, employing techniques such as value chain analysis.

$\checkmark$ Sustainability of the natural and cultural environment considers policies and actions to conserve the asset base, to manage tourism in sensitive areas and secure benefits from it. Specific attention is paid to mitigation and adaptation of the tourism sector to climate change (Sustainable Tourism for Development, Guidebook 2013).

The European Commission launched the European Tourism Indicator System (ETIS) in 2013 with the aim helping destinations to monitor and measure their sustainable tourism performance, by using a common comparable approach. The ETIS was based on some core indicators and optional indicators, subdivided into four categories:

1. Destination management (Sustainable tourism and public policy, Customer satisfaction),

2. Social and cultural impact (Community/social impact, Health and safety, Gender equality, Inclusion/accessibility, Protecting and enhancing cultural heritage, local identity and assets),

3. Economic value (Tourism flow (volume and value) at destination, Tourism enterprise(s) performance, Quantity and quality of employment, Tourism supply chain),

4. Environmental impact (Reducing transport impact, Climate change, Solid waste management, Sewage treatment, Water management, Energy usage, Landscape and biodiversity protection)(The European Tourism Indicator System, 2016).

\section{Methods}

The purpose of the research is to assess sustainable tourism development in the Republic of Armenia. The object of the research is sustainable tourism in Armenia. The subject of this research is sustainable tourism issues by some indicators in Armenia. In the research a variety of data are used from the National Statistical Service of RA, The World Travel \& Tourism Council (WTTC) and other national and international organizations, state organs, medias, etc.

The main methods used in the research are qualitative and quantitative assessments of sustainable tourism in Armenia by using the following seven dimensions (methodology by L.Cernat, J. Gourdon, 2007) tourism assets; tourism activity; tourism-related linkages; tourism-related leakages; environmental and social sustainability; overall infrastructure; attractiveness. The indicators range from 1 to 100 (Appendix 1, Table 1). The scores are approximate evaluations based on available statistical data and reports.

\section{Discussion}

In Armenia there is not any program of sustainable tourism development. However, the need of sustainable development is fixed in tourism development concept of Armenia adopted in 2008. It is accepted that the 
investments in tourism sphere should be accurately planned and managed to insure the accomplishment of sustainable development needs. Sustainable development requires cooperation of all stakeholders. The necessity of sustainable development is connected with the fact that tourism develops based on natural, historicalcultural and human resources and these resources need to be maintained and reproduced. The aim of sustainable development must be to ensure positive impact of tourism on nature, culture and economic situation. For insuring sustainability it is necessary to provide sustainable transport, environment, rational use of natural resources, maintenance of cultural heritage, social equity, developed infrastructures and high level of services, balanced territorial economic development.

\section{Table 1. Sustainable tourism evaluation in Armenia}

\begin{tabular}{|c|c|c|c|}
\hline Dimension & Indicator & Current State in Armenia & Score \\
\hline 1. Tourism Assets & $\begin{array}{l}\text { Natural assets (comprised of activities } \\
\text { related to the natural environment and } \\
\text { provide opportunities for beach and ma- } \\
\text { rine tourism, hiking, skiing or mountain- } \\
\text { eering, ecotourism, wildlife viewing, } \\
\text { fishing and hunting) } \\
\text { Cultural assets (cultural heritage, muse- } \\
\text { ums, archaeological sites, architecture or } \\
\text { crafts, major cultural and sports events, } \\
\text { etc.) }\end{array}$ & $\begin{array}{l}\text { Armenian nature provides opportunities for hiking, skiing, } \\
\text { mountaineering, beach tourism (Sevan), ecotourism, wild- } \\
\text { life viewing. } \\
\text { Armenia has a rich cultural heritage, } 24221 \text { historical-cul- } \\
\text { tural monuments, } 106 \text { museums, archaeological sites. } \\
\text { In } 2017 \text { tourism competitiveness report (The Travel \& } \\
\text { Tourism Competitiveness Report, 2017) Armenia was the } \\
\text { 89th with the natural resources index, } \\
\text { 74th with the Attractiveness of natural assets, } \\
\text { 99th with the Cultural resources and business travel, } \\
\text { 61st with the Number of World Heritage cultural sites ( } 3 \\
\text { sites), } \\
\text { 113rd with the Sports stadium index (1 stadium), } \\
\text { 107th with the Number of international association meet- } \\
\text { ings, } \\
\text { 95th with the Cultural and entertainment tourism digital } \\
\text { demand. }\end{array}$ & 65 \\
\hline 2. Tourism activity & $\begin{array}{l}\text { Number of tourists } \\
\text { Tourism revenues } \\
\text { (Such indicators should be further dis- } \\
\text { aggregated by type of travel, trip and } \\
\text { transport, country of origin and purpose } \\
\text { of visit. Such detailed statistics could } \\
\text { shed some light on a number of specific } \\
\text { characteristics of tourism, such as the } \\
\text { extent to which a tourism destination is } \\
\text { engaged in high-value tourism) }\end{array}$ & $\begin{array}{l}\text { Here the main statistics of Armenia is poor. We have only } \\
\text { the number of incoming tourists, country of origin. The } \\
\text { purpose of visits shows only the purpose of those, who } \\
\text { stayed in hotels. } \\
\text { In } 20171.494 .779 \text { tourists visited Armenia ( } 18.7 \% \text { more } \\
\text { than last year), } 264.702 \text { tourists stayed in hotels. } \\
20.3 \% \text { of incoming tourists were from Russia, } 13.6 \% \text { from } \\
\text { USA, } 14.2 \% \text { from Iran, } 21.3 \% \text { from EU countries. } \\
\text { The purpose of } 23.9 \% \text { tourists was business, } 52.8 \% \text { trav- } \\
\text { eled for rest and leisure (The Socio-economic condition of } \\
\text { the RA, } 2018 \text { January) } \\
\text { According to the data of Balance of Payments of Armenia } \\
\text { (Balance of Payments of Armenia, } 2017 \text { ), the receipts } \\
\text { from international tourists were } 1269,5 \text { mn USD in 2017, } \\
\text { dividing this sum on the number of incoming tourists, we } \\
\text { will get the average receipts per arrival, which is } 850 \text { USD. }\end{array}$ & 70 \\
\hline $\begin{array}{l}\text { 3. Tourism related } \\
\text { linkages (captured } \\
\text { by the multiplier ef- } \\
\text { fect of the tourism } \\
\text { sector on the overall } \\
\text { economy) }\end{array}$ & $\begin{array}{l}\text { The tourism industry linkage index } \\
\text { measures the indirect effect of tourism } \\
\text { industry on GDP. The tourism economy } \\
\text { linkage index measures the effect on } \\
\text { GDP of the development of tourism in- } \\
\text { dustry (capital investment, government } \\
\text { expenditure and non-visitor exports). }\end{array}$ & $\begin{array}{l}\text { Based on WTTC data (World Travel and Tourism council, } \\
\text { Armenia, 2018) the direct contribution of Travel \& Tour- } \\
\text { ism to GDP was AMD231.7bn (USD477.7mn), } 4.4 \% \text { of } \\
\text { total GDP in } 2017 \text {. } \\
\text { The total contribution of Travel \& Tourism to GDP was } \\
\text { AMD834.1bn (USD1,719.7mn), } 15.7 \% \text { of GDP in } 2017 \text {. } \\
\text { Travel \& Tourism investment in } 2017 \text { was AMD52.8bn, } \\
4.6 \% \text { of total investment. } \\
\text { Government collective spending was } 21,6 \text { bn AMD. } \\
\text { GDP multiplier is } 3,6 \text {. }\end{array}$ & 80 \\
\hline
\end{tabular}


Table 1 (cont.). Sustainable tourism evaluation in Armenia

\begin{tabular}{|c|c|c|c|}
\hline Dimension & Indicator & Current State in Armenia & Score \\
\hline $\begin{array}{l}\text { 4. Tourism-related } \\
\text { leakages: } \text { missed op- } \\
\text { portunities }\end{array}$ & $\begin{array}{l}\text { Internal leakages are losses due to tour- } \\
\text { ism activities that originate in the eco- } \\
\text { nomic space of the tourism service pro- } \\
\text { vider and are paid and accounted for do- } \\
\text { mestically. It generally refers to the "im- } \\
\text { port coefficient" of tourism, or the pro- } \\
\text { portion of imported goods needed to } \\
\text { provide the service. } \\
\text { External leakages are opportunity costs } \\
\text { that originate outside the economic } \\
\text { space of the tourism service provider } \\
\text { and are not accounted for domestically. } \\
\text { The leakage effects can be assessed us- } \\
\text { ing the net balance of foreign exchange } \\
\text { (which is the difference between earn- } \\
\text { ings from tourist expenditure and the in- } \\
\text { put imports for tourism), or the net for- } \\
\text { eign exchange earnings ratio for tour- } \\
\text { ism. }\end{array}$ & $\begin{array}{l}\text { Visitor exports were } 529,8 \text { bn AMD, } \\
\text { Internal tourism consumption was } 632,6 \text { bn AMD (visi- } \\
\text { tor exports + domestic expenditure), } \\
\text { Purchases by tourism providers, including imported } \\
\text { goods were: }-400.9 \mathrm{bn} \text { AMD, so the net balance of for- } \\
\text { eign exchange will be: } 231,7 \text { bn AMD. }\end{array}$ & $\begin{array}{l}\quad 70 \\
\text { (A high } \\
\text { score in the } \\
\text { leakage } \\
\text { field means } \\
\text { that the } \\
\text { country has } \\
\text { few leak- } \\
\text { ages rela- } \\
\text { tively to the } \\
\text { tourism ac- } \\
\text { tivity) }\end{array}$ \\
\hline $\begin{array}{l}\text { 5. Environmental } \\
\text { and social sustaina- } \\
\text { bility (The social di- } \\
\text { mension quantifies } \\
\text { the involvement of } \\
\text { local communities in } \\
\text { various tourism ac- } \\
\text { tivities. The environ- } \\
\text { mental aspect as- } \\
\text { sesses the implemen- } \\
\text { tation of environmen- } \\
\text { tal and quality stand- } \\
\text { ards agreed by rele- } \\
\text { vant international or- } \\
\text { ganizations for tour- } \\
\text { ism projects and allo- } \\
\text { cation of tourism rev- } \\
\text { enues to prevent deg- } \\
\text { radation of resources } \\
\text { in the destination } \\
\text { country). }\end{array}$ & $\begin{array}{l}\text { The number of jobs created by the tour- } \\
\text { ism sector (direct employment in the } \\
\text { tourism sector and indirect employment } \\
\text { in other sectors). } \\
\text { The average wage in tourism relative to } \\
\text { the average wage in the economy (as- } \\
\text { sesses the extent to which tourism rep- } \\
\text { resents a high-value activity). } \\
\text { Tourism-related tax revenues (these } \\
\text { taxes can provide financial resources for } \\
\text { infrastructure development, public facil- } \\
\text { ities and services that can improve the } \\
\text { living standards of local communities). } \\
\text { The number of protected area or the } \\
\text { tourism-related tax revenues devoted to } \\
\text { environment protection. } \\
\text { The actual environmental quality needs } \\
\text { to be quantified, using several indicators } \\
\text { such as the number of endangered spe- } \\
\text { cies, CO } 2 \text { emissions, etc. } \\
\text { The number of environment-related in- } \\
\text { ternational agreements signed by a } \\
\text { country is a good indicator of the com- } \\
\text { mitment for environmental protection. } \\
\text { The impact of the actual level of tourism } \\
\text { activity on environment (to determine } \\
\text { the tourism density (e.g. the number of } \\
\text { tourists per square km). This requires } \\
\text { weighting the number of arrivals during } \\
\text { a certain period (e.g. a month) by the } \\
\text { length of stay. }\end{array}$ & $\begin{array}{l}\text { Direct contribution of Travel \& Tourism to employment } \\
\text { was } 44,500 \text { jobs ( } 3.9 \% \text { of total employment). } \\
\text { Total contribution of Travel \& Tourism to employment } \\
\text { was } 162,000 \text { jobs ( } 14.1 \% \text { of total employment). } \\
\text { The average wage in hotel and catering service was } \\
128,286 \text { AMD in } 2017 \text {, the average wage in the economy } \\
\text { was } 195,074 \text { AMD(The Socio-economic condition of } \\
\text { the RA, } 2018 \text { January) } \\
\text { There are no tourism-related taxes in Armenia. } \\
\text { There are only payments for use of natural resources and } \\
\text { nature protection tax. } \\
\text { The number of national parks and State reserves was } 7 \text {, } \\
\text { with } 269,0 \text { thousand ha area, and the number of state } \\
\text { sanctuaries was } 27 \text {, with } 114,1 \text { thousand ha area (Envi- } \\
\text { ronmental statistics of Armenia for } 2017 \text { and time-series } \\
\text { of indicators for } 2013-2017 \text { ). } \\
\text { In } 2017 \text {, emissions into atmosphere comprised } 291.1 \\
\text { thsd. t. The quantity of hazardous substances emitted } \\
\text { into atmosphere from stationary sources comprised } \\
\text { 141.3 thsd. t. In } 2017 \text { the quantity of hazardous sub- } \\
\text { stances emitted into atmosphere from mobile sources } \\
\text { comprised } 149.8 \text { thsd. t.(Environment and natural re- } \\
\text { sources in RA for } 2017 \text { ). } \\
\text { There are many international agreements and conven- } \\
\text { tions signed by Armenia about environmental protection } \\
\text { (Participation of the Republic of Armenia in the interna- } \\
\text { tional environmental agreements). } \\
\text { In } 2017 \text { tourism competitiveness report Armenia was the } \\
102 \text { nd with the Environmental sustainability index, ac- } \\
\text { cording to their data the } 6,3 \% \text { of species are threatened. } \\
\text { The monthly data about tourist arrivals and length of stay } \\
\text { are not available and so the tourism density cannot be } \\
\text { calculated accurately. }\end{array}$ & 55 \\
\hline
\end{tabular}


Table 1 (cont.). Sustainable tourism evaluation in Armenia

\begin{tabular}{|c|c|c|c|}
\hline $\begin{array}{l}\text { 6. Overall } \\
\text { infrastructure }\end{array}$ & $\begin{array}{l}\text { Transport infrastructure } \\
\text { Electricity } \\
\text { Water access } \\
\text { ICT infrastructure } \\
\text { Accommodation } \\
\text { Restaurants } \\
\text { Entertainment facilities }\end{array}$ & $\begin{array}{l}\text { According to Tourism competitiveness report } 2017 \text {, Ar- } \\
\text { menia was } \\
\text { the } 88 \text { th with the Air transport, Ground and port infra- } \\
\text { structure indexes, } \\
\text { the } 71 \text { st with the ICT readiness, } \\
\text { 1st with the mobile network coverage, } \\
71 \text { st with the quality of electricity supply, } \\
\text { 1st with the access to improved drinking water, } \\
\text { the } 74 \text { th with the tourist service infrastructure, } \\
\text { the } 65 \text { th with the number of hotel rooms ( } 556 \text { hotels in } \\
\text { Armenia). } \\
\text { There were } 1663 \text { restaurants in Armenia in } 2017 \text {. }\end{array}$ & 60 \\
\hline 7.Attractiveness & $\begin{array}{l}\text { Price competitiveness (a mix of the ho- } \\
\text { tel price index, the purchasing power } \\
\text { parity index). } \\
\text { The index on human resources (mainly } \\
\text { based on the education index), safety } \\
\text { and security. }\end{array}$ & $\begin{array}{l}\text { According to Tourism competitiveness report } 2017 \text {, Ar- } \\
\text { menia was } \\
\text { the } 80 \text { th with the Price competitiveness index, } \\
57 \text { th with the purchasing power parity index, } \\
111 \text { st with the ticket taxes and airport charges, } \\
45 \text { th with the human resources and labour market index, } \\
59 \text { th with the Primary education enrollment rate, } \\
79 \text { th with the Secondary education enrollment rate, } \\
34 \text { th with the safety and security, } \\
57 \text { th with the index of terrorism incidence. }\end{array}$ & 65 \\
\hline
\end{tabular}

\section{Conclusion}

So, tourism sustainability was assessed based on a number of quantitative indicators. Figure 1 (See Appendix 2 , Figure 1) illustrates interactions between seven dimensions. The link between assets and activity shows that the country is able to increase the tourism value exploiting its tourism asset. The connection between activity and linkages assesses the capacity of the tourism sector to contribute to the activity of other economic sectors. The interaction between linkages and leakages shows if tourism could be more beneficial to the local economy and detects ways to transform leakages into linkages. The connection between activity and sustainability shows if tourism activities are sustainable both in environmental and social aspects. The link between activityinfrastructure shows if the infrastructure is sufficiently developed to respond to tourism demand and to support tourism development. The connection attractiveness-activity shows if the country is sufficiently attractive to enhance tourism activity, being a key factor in choosing a destination by tourists. So, higher attractiveness index would have a positive impact on tourism activity.

Based on the available data and evaluations of Armenia, we may resume, that the country has enough tourism assets, but there is a need to make them more attractive to form a touristic product and to attract tourists. Tourism has a great contribution to the economy; its multiplier effect shows that 1 foreign dollar creates 3.6 new dollars in the economy. We still have a problem concerning environmental and social sustainability. Armenia is the 102nd among 136 countries with the Environmental sustainability index. The infrastructure is also not developed sufficiently. We have problems with transport infrastructure, tourist service infrastructure, ICT readiness. We have also problems with attractiveness. Our airport tickets are high, although our safety and security conditions are normal, however price competitiveness is an essential indicator to choose the destination by tourists. So, the main key issues which need careful actions are connected with infrastructures, price attractiveness and environmental and social sustainability.

There is a need to elaborate sustainable tourism development strategy in Armenia which will ensure positive impact on economic and social condition, environment and cultural heritage.

For a sustainable development it is necessary to change people's mentality, lifestyle, behavior, rooted value system. One of the priorities is the formation of public consciousness, as well as knowledge of other aspects of ecology and sustainable tourism. Tourist organizations should use green licenses or ecolabels, use renewable energy sources, ensure sustainable landfill and waste management, use of electric or hybrid vehicles, etc. Sustainable tourism development in Armenia should contribute to socio-economic, cultural and environmental development of the country. It should contribute to the creation of jobs, poverty reduction, infrastructure development, equal economic development of the regions, rational use of natural resources, natural and environmental protection, preservation of cultural values, solution of people's social issues, human capital development, community development, the development of other sectors of the economy, etc. 


\section{References}

1. Ashley, C., Roe, D., and Goodwin, H. (2001). Pro-Poor Tourism Strategies: Making Tourism Work for the Poor, A review of experiencee Overseas Development Institute, London, The International Institute for Environmental Development, London, and Centre for Responsible Tourism, London. Available at: www.propoortourism.org.uk.

2. Balance of Payments of Armenia [Electronic resource]. Available at: https://www.cba.am/am/sitepages/statexternalsector.aspx (Accessed: 10.01.19)

3. Barlet Sandra, Collombon Jean-Marie (2004). Approches de quelques définitions. In Tourisme solidaire et développement durable, Les Éditions du Gret, Paris

4. Baumgartner, C. (2008) What is Sustainable Tourism? Trademark of Naturefriends International for Sustainable Tourism Development, Vienna.

5. Bramwell, B. and Lane, B. (1993). Sustaining tourism: An evolving global approach. Journal of Sustainable Tourism, 1(1), 1-5.

6. Butler, R.W. (1980). The concept of a tourist area cycle of evolution: Implications for management of resources. Canadian Geographer, 24(1), 5-12.

7. Butler, R. (1993). Tourism- an evolutionary perspective. In J.G Nelson, R.W. Butler and G. Wall (eds.) Tourism and Sustainable Development: Monitoring, Planning, Management (pp. 27-43). Waterloo: University of Waterloo Press.

8. Carlsen, J. (1997). A systems approach to understanding ecologically sustainable development of tourism (ESDT). In B. Faulkner, C. Tisdell and D. Weaver Progress in Tourism and Hospitality Research Part 1 (pp. 249-56) . Proceedings of the 8th Australian Tourism and Hospitality Research Conference. Gold Coast Canberra: Bureau of Tourism Research.

9. Cernat L., Gourdon J. (2007). Is the concept of sustainable tourism sustainable? Developing the sustainable tourism benchmarking tool, United Nations, New York and Geneva.

10. Coccossis, H. (1996). Tourism and sustainability: Perspective's and implications. In G.K. 492 Journal of Sustainable Tourism. Priestly, J.A. Edwards and H. Coccossis (eds.) Sustainable Tourism? European Experiences ( $\mathrm{pp}$ 1-21). Oxon, UK: CAB International.

11. Ding, P. and Pigram, J. (1995). Environmental audits: An emerging concept in sustainable tourism development. Journal of Tourism Studies, 6(2), 2-10.

12. Driml, S.M. (1996). Sustainable tourism in protected areas? Unpublished PhD thesis, Australian National University, Canberra.

13. Environmental statistics of Armenia for 2017 and time-series of indicators for 2013-2017. [Electronic resource]. Available at: https://www.armstat.am/file/article/eco_booklet_2017.pdf.

14. Environment and natural resources in RA for 2017, [Electronic resource]. Available at: https://www.armstat.am/file/article/eco book 2017 8.pdf (Accessed: 10.01.19).

15. Hunter, C. (1995) On the need to re-conceptualize sustainable tourism development. Journal of Sustainable Tourism, 3(3), 155-65.

16. Hunter, C. (1997). Sustainable tourism as an adaptive paradigm. Annals of Tourism Research, 24(4), $850-867$.

17. Making Tourism More Sustainable (2005). A Guide for Policy Makers, United Nations Environment Programme and World Tourism Organization.

18. Muller, H. (1994). The thorny path to sustainable tourism development. Journal of Sustainable Tourism, 2(3), 131-6.

19. Neto, F. (2002). Sustainable Tourism, Environmental Protection and Natural Resource Management: Paradise on Earth? United Nations.

20. Participation of the Republic of Armenia in the international environmental agreements. [Electronic resource]. Available at: http://mnp.am/uploads/1/1523357238tab-Eng large.pdf; http://mnp.am/en/pages/148(Accessed: 10.01.19).

21. Rosenow, J.E., Pulsipher, G.L. (1979). Tourism: The Good, the Bad and the Ugly. Nebraska: Media Productions and Marketing. 
22. Sadler, B. (1993). Introduction. in S. Hawkes and P. Williams (eds) The Greening of Tourism from Principles to Practice: A Casebook of Best Environmental Practice in Tourism (pp. vi-xi). Canada: Centre for Tourism Policy and Research Simon Fraser University.

23. Stankey, G. (1973). Visitor Perception Wilderness Recreation Carrying Capacity. Utah: USDA Forest Service.

24. Sustainable Tourism for Development Guidebook (2013). UNWTO.

25. Tao (2005). Sustainable Tourism Development. Ohauo University.

26. Tivy, J. (1973) The Concept and Determination of Carrying Capacity of Recreational Land in the USA. Occasional Paper number 3. Scotland: Countryside Commission for Scotland.

27. The European Tourism Indicator System (2016). ETIS toolkit for sustainable destination management, European Union.

28. The Travel \& Tourism Competitiveness Report 2017. [Electronic resource]. Available at: http://www3.weforum.org/docs/WEF_TTCR_2017_web_0401.pdf(Accessed: 10.01.19).

29. The Socio-economic condition of the RA in 2018 January. [Electronic resource]. Available at: https://www.armstat.am/file/article/sv_01_18a_421.pdf, (Accessed: 10.01.19) Available at: https://www.armstat.am/file/article/sv 01 18a 142.pdf(Accessed: 10.01.19).

30. Tourism will never be completely sustainable as every industry has impacts, but it can work towards becoming more sustainable, Sustaining tourism. [Electronic resource] Available at: https://sustainabletourism.net/ (Accessed 20.02.2019).

31. Travel \& Tourism Economic Impact World (2018). World Travel and Tourism Council. p. 1.

32. UNEP (2002). Sustainable Tourism, Turning the Tide [Electronic resource]. Available at: https://www.earthsummit2002.org/es/issues/tourism/tourism.pdf (Accessed: 10.01.19).

33. UNWTO (2016). Tourism Highlights, Edition, p. 3 [Electronic resource]. Available at: http://www.eunwto.org/doi/pdf/10.18111/9789284418145 (Accessed 20.02.2019).

34. Wall, G. (1997) Is ecotourism sustainable? Environmental Management, 21(4), 483-91.

World Travel and Tourism council, Armenia, 2018, [Electronic resource]. Available at:

https://www.wttc.org/-/media/files/reports/economic-impact-research/countries-2018/armenia2018.pdf (Accessed: 10.01.19).

Appendix 1

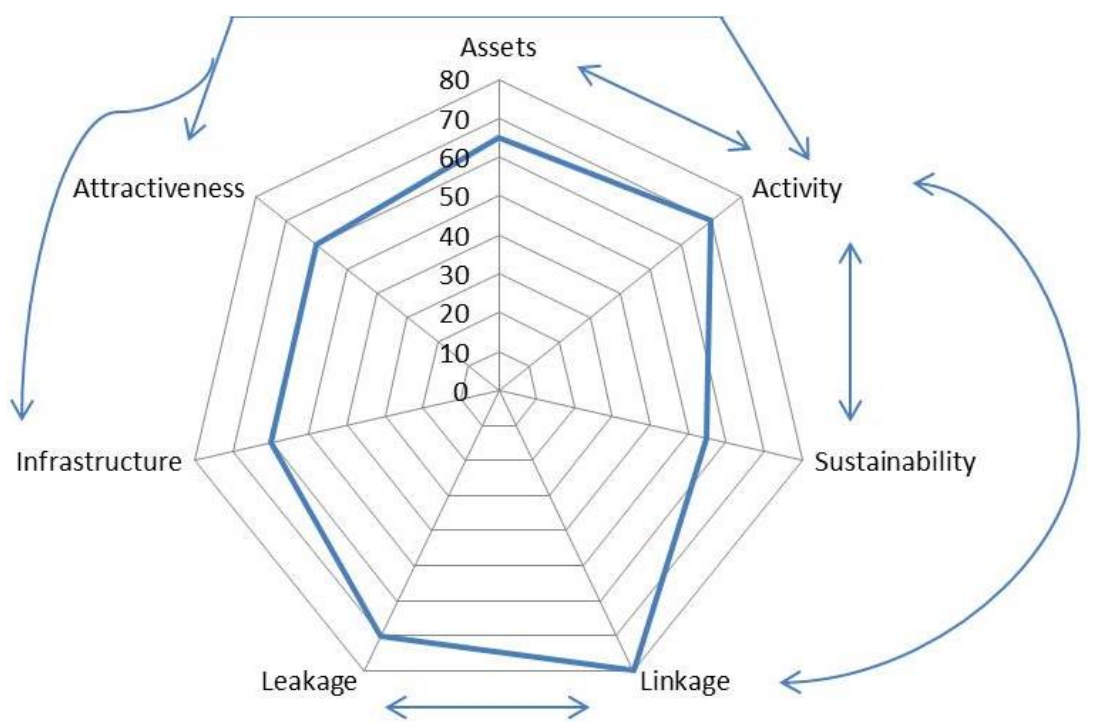

Figure 1. The sustainable tourism chart of Armenia 